\title{
PENGEMBANGAN KETERAMPILAN BERPIKIR TINGKAT TINGGI BERBASIS STRATEGI METAKOGNITIF PROBLEM SOLVING PADA SISWA SEKOLAH DASAR DI KLATEN
}

\author{
Ummu Hany Almasitoh ${ }^{1}$, Theresia Kriswianti Nugrahaningsih ${ }^{2}$. \\ 1,2 Universitas Widya Dharma Klaten, Indonesia.
}

Email: ummu.hany16@gmail.com ${ }^{1}$, theresiakriswianti@gmail.com ${ }^{2}$.

\begin{abstract}
This research is motivated by the low ability of grade $V$ elementary school students in thinking logically and rationally. Such conditions encourage researchers in the field of education to design to be able to equip students who are responsive to globalization in the era of challenges. To face these challenges, researchers need to train students to be able to learn independently and develop their ability to reason and think. This is in line with the research objectives of how learning from elementary schools is to form intellectual humans, be able to solve problems and be able to think / reason based on metacognitive problem solving. The research location is an elementary school that has implemented Curriculum 13 in the Klaten City sub-district. The research subjects were students of grade V Elementary School. The method used in the study was pre-experimental with a one-group pretest-posttest design by taking only one experimental group as the sample, without taking the control group on the grounds that this study only saw the extent of the improvement of metacognition-based high-order thinking skills through the application of the problem learning model. solving without having to compare it with other lessons. Based on the research results, the use of problem solving metacognitive strategies is a learning strategy that considers and is able to develop students' higher order thinking skills. This is indicated by the mean score of the pretest test score is 67.6; The mean posttest score was 87.7, and N-Gain 62 (100\%) was in the moderate category.
\end{abstract}

Keywords: Higher order thinking skills, metacognitive and problem solving.

\begin{abstract}
ABSTRAK
Penelitian ini dilatarbelakangi oleh kemampuan siswa kelas V Sekolah Dasar dalam berpikir logis dan rasional masih rendah. Kondisi demikian mendorong peneliti di bidang pendidikan mendesain untuk mampu membekali siswa yang tanggap terhadap tantangan era globalisasi. Untuk menghadapi tantangan tersebut, maka peneliti perlu melatih siswa agar mampu belajar secara mandiri dan berkembang kemampuan bernalar serta berpikirnya. Hal ini sejalan dengan tujuan penelitian bagaimana pembelajaran dari sekolah dasar yaitu membentuk manusia intelektual, mampu memecahkan permasalahan serta mampu berpikir/bernalar berbasis metakognitif problem solving. Lokasi penelitian adalah Sekolah Dasar yang telah menerapkan kurikulum 13 yang berada di kecamatan Kota Klaten. Subyek penelitian adalah siswa kelas V Sekolah Dasar. Metode yang digunakan dalam penelitian adalah pra-eksperimental dengan desain one group pretest-posttest design dengan hanya mengambil satu kelompok eksperimen sebagai sampel, tanpa mengambil kelompok kontrol dengan alasan bahwa penelitian ini hanya melihat sejauhmana peningkatan keterampilan berpikir tingkat tinggi berbasis metakognisi melalui penerapan model pembelajaran problem solving tanpa harus membandingkannya dengan pembelajaran yang lain. Berdasarkan hasil penelitian membuktikan bahwa penggunaan strategi metakognitif problem solving merupakan alternatif strategi pembelajaran yang dipertimbangkan dan mampu mengembangkan keterampilan berpikir tingkat tinggi siswa. Hal ini ditunjukkan dari skor rerata skor tes pretest adalah 67.6; rerata skor posttest 87.7, dan N-Gain 62 (100\%) dalam kategori sedang.
\end{abstract}

Kata kunci : Keterampilan berpikir tingkat tinggi, Metakognitif dan problem solving.

\section{PENDAHULUAN}

Salah satu hambatan dalam pembelajaran adalah kemampuan siswa dalam berpikir logis dan rasional masih rendah. Gagasan awal dari penelitian ini adalah atas diberlakukannya kurikulum 2013 yang menekankan aktivitas siswa dalam pembelajaran. Penelitian ini dilaksanakan juga dilandasi oleh bahwa selama ini para 
pendidik belum optimal dalam mengajari siswanya dengan strategi belajar. Pemandangan umum yang terlihat adalah bahwa siswa dibiarkan sendiri dengan gaya membacanya masing masing dan ada kecenderungan pendidik kurang memberikan bimbingan.

Berdasarkan hasil penelitian Wooley (2010) bahwa siswa yang mengalami hambatan kognitif kebanyakan gagal ketika memahami bahan bacaan karena sebagian besar kemampuan kognitifnya hanya difokuskan untuk menghafalkan secara tepat kalimat dalam bacaan, namun hanya sedikit yang berusaha memahami maksud bacaan. Disamping itu kenyataan bahwa sangat jarangnya pendidik mengajarkan strategi belajar kepada para siswa nampaknya merupakan penyebab paling besar kegagalan siswa dalam memahami materi ajar (Riyadi, 2010). Hal keadaan ini akan berkontribusi besar terhadap rendahnya pencapaian siswa pada mata pelajaran tertentu.

Untuk meningkatkan keterampilan berpikir siswa, pendidik dituntut kreatif untuk menciptakan suasana belajar yang kondusif dan menggunakan berbagai strategi pembelajaran serta media yang dapat memfasilitasi siswa. Strategi pembelajaran yang ideal untuk menumbuhkembangkan keterampilan berpikir tingkat tinggi adalah dengan meningkatkan keterampilan metakognisinya. Keterampilan metakognitif diperlukan untuk mengelola kecakapan kognitif dan mampu melihat kelemahannya sehingga dapat dilakukan refleksi pada tindakan berikutnya. Dengan strategi metakognitif memungkinkan siswa dapat melakukan perencanaan, mengikuti perkembangan, dan memantau proses belajarnya (Susan, 2002).

Lebih lanjut diperkuat hasil penelitian yang telah dilakukan Flavell (1976), bahwa siswa yang tidak berhasil menerapkan strategi yang telah diajarkan oleh pendidik, karena tidak menyadari aspek lain dari belajar, yaitu tidak hanya mengandalkan kemampuan menggunakan strategi mneumonic (menghafal) tetapi juga mampu dalam menggunakan strategi memonitor dan mengatur proses memori selama mereka menggunakan strategi pembelajaran.

Berbagai penelitian menunjukkan bahwa banyak siswa memiliki keterampilan dasar dalam mengerjakan tugas akademik, akan tetapi kebanyakan lemah dalam menggunakan strategi belajar (Hattie, 2009). Meskipun penelitian-penelitian tersebut secara konsisten menunjukkan hasil yang membuktikan bahwa metakognisi mampu meningkatkan prestasi belajar siswa, namun penelitian-penelitian tersebut masih sangat terbatas pada intervensi metakognisi secara terpisah-pisah (Kiewra, 2001; Kirgoz, 2009). Hal inilah yang menjadi ketertarikan peneliti untuk meneliti lebih spesifik bagaimana meningkatkan keterampilan berpikir tingkat tinggi berbasis strategi metakonitif problem solving dalam pembelajaran Sekolah Dasar.

\section{METODE PENELITIAN}

Penelitian ini termasuk jenis penelitian dan pengembangan $(R \& D)$, yakni penelitian yang berorientasi pada pengembangan suatu produk yang proses pengembangannya dideskripsikan secara teliti dan produk yang diperoleh, dievaluasi. Metode yang digunakan dalam penelitian ujicoba terbatas adalah pra-eksperimental dengan desain one group pretest-posttest design dengan hanya mengambil satu kelompok eksperimen sebagai sampel, tanpa mengambil kelompok kontrol dengan alasan bahwa penelitian ini hanya melihat sejauhmana peningkatan kemampuan metakognisi melalui penerapan model pembelajaran problem solving tanpa harus membandingkannya dengan pembelajaran yang lain.

Kemudian peningkatan keterampilan berpikir tingkat tinggi berbasis strategi metakognitif problem solving diukur menggunakan perhitungan gain score. Dengan menggunakan nilai tes yakni nilai pretest dan postest yang telah didapat, selanjutnya diolah menggunakan rumus sebagai berikut 


$$
g=\frac{X 2-X 1}{X m a k s-X 1}
$$

Keterangan: $X 1=$ nilai pretest

$X 2=$ nilai postest

$X m a k s=$ nilai maksimal

Selanjutnya hasil perhitungan di atas dibandingkan melalui tabel berikut untuk mendapatkan kriteria peningkatan keterampilan berpikir tingkat tinggi berbasis strategi metakognitif problem solving siswa (Hake \& Richard, 2002)..

Tabel 1 Kriteria gain score

\begin{tabular}{cc}
\hline Gain Score & Kriteria \\
\hline$g \geq 0.7$ & Tinggi \\
\hline $0.3 \leq g<0.7$ & Sedang \\
\hline$g<0.3$ & Rendah \\
\hline
\end{tabular}

Sumber data penelitian ini meliputi:

1. Informan, pendidik mata pelajaran di lokasi penelitian dan siswa.

2. Peristiwa berlangsungnya pembelajaran.

3. Dokumen, yaitu jenis informasi tertulis, yang berupa buku, artikel, jurnal, pedoman, silabus, RPP, Modul, media pembelajaran yang ada, model pembelajaran yang dikembangkan, data pendidik, dan data siswa.

Sesuai dengan sumber data di atas, teknik pengumpulan data yang digunakan dalam penelitian ini meliputi:

1. Studi kepustakaan

Studi kepustakaan, dengan menggali informasi, hasil riset dan pengumpulan referensi pendukung, jurnal penelitian yang berkaitan dengan berbagai strategi belajar metakognisi, teori metakognisi, teori problem solving, teori research \& development, untuk melengkapi kajian teori.

2. Wawancara

Wawancara dilakukan untuk memperoleh data tentang profil pendidik dan tanggapan siswa tentang pembelajaran.

3. Observasi

Jenis observasi yang dilakukan adalah observasi berpartisipasi. Observasi atau pengamatan dilakukan untuk menggali data yang berkaitan dengan penerapan strategi metakognitif problem solving dalam meningkatkan keterampilan berpikir tingkat tinggi yang selama ini dilakukan oleh para pendidik.

4. Analisis Dokumen

Analisis dokumen dilakukan terhadap semua informasi tertulis, baik yang tersurat maupun yang tersirat yang terkait dengan penelitian ini.

Data penelitian terdiri atas dua jenis, yaitu data yang bersifat kualitatif dan kuantitatif. Data kualitatif meliputi isi materi ajar, model pengembangan pembelajaran, RPP dan penerapan keterampilan berpikir tingkat tinggi berbasis strategi belajar metakognisi problem solving pada mata pelajaran. Mengingat kedua jenis data tersebut, teknik analisis data yang digunakan meliputi:

1. Analisis deskriptif kualitatif untuk mengetahui keadaan pembelajaran.

2. Analisis deskriptif kuantitatif berupa tes. Tes ini mencakup indikator-indikator metakognisi dalam komponen prediksi, perencanaan, pemonitoran, evaluasi, deklarasi, prosedural, dan kondisional (Brown, dalam Desoete et al., 2001). Tes yang dikembangkan untuk mengukur dalam bentuk pilihan berganda yang terdiri dari 20 
butir.

\section{HASIL DAN PEMBAHASAN}

Hasil pengembangan keterampilan berpikir tingkat tinggi berbasis strategi metakognitif problem solving yang dikembangkan dengan uji N.Gain.

1. Aktivitas siswa selama proses pembelajaran

\begin{tabular}{|c|c|c|}
\hline Fase & Indikator & Aktivitas Pendidik \\
\hline 1 & siswa pada & $\begin{array}{l}\text { suatuMenjelaskan tujuan pembelajaran, } \\
\text { menjelaskan logistic yang dibutuhkan dan } \\
\text { memotivasi siswa terlibat pada aktivitas } \\
\text { pemecahan masalah }\end{array}$ \\
\hline 2 & $\begin{array}{l}\text { Mengorganisasi } \\
\text { belajar }\end{array}$ & $\begin{array}{l}\text { ketikaMembantu siswa mendefinisikan dan } \\
\text { mengorganisasikan tugas belajar yang } \\
\text { berhubungan dengan masalah tersebut. }\end{array}$ \\
\hline 3 & $\begin{array}{l}\text { Membimbing pengalaman } \\
\text { dalam berkelompok }\end{array}$ & $\begin{array}{l}\text { siswaMendorong siswa mengumpulkan infomasi } \\
\text { yang sesuai, melaksanakan ekperimen } \\
\text { untuk mendapatkan penjelasan dan } \\
\text { pemecahan masalah }\end{array}$ \\
\hline
\end{tabular}

Ketika melakukan uji coba kepada siswa, pendidik memberikan sebuah artikel yang berjudul "Fenomena Kenakalan pada Anak" berupa pertanyaan-pertanyaan yang diberikan oleh pendidik untuk dijawab dengan baik dan benar oleh siswa. berupa definisi artikel, informasi-informasi yang ditemukan, diantaranya, latar belakang masalah, kapan terjadi masalah, dan bagaimana masalah itu dapat terjadi, bagaimana menemukan informasi kemudian mereka dapat memberikan kritik beserta solusinya.

Langkah berikutnya, siswa dibagi menjadi 7 kelompok. Satu kelompok terdiri dari 5 siswa dan setiap kelompok mendapat satu buah artikel, panduan pertanyaan, nama kelompok, dan lembar penilaian untuk setiap individu. Nama kelompok bertujuan untuk memudahkan kelompok lain dalam proses penilaian. Tugas masing-masing kelompok yakni mendiskusikan dan mencari permasalahan serta memberikan solusi yang terdapat pada artikel. Setiap kelompok juga mendapat panduan pertanyaan sebagai bahan diskusi. Setelah itu, mereka akan membagi tugas yang akan disampaikan ketika presentasi nanti, setiap siswa mendapat tugas satu-satu. Setelah diskusi kelompok selesai, maka tiap kelompok maju ke depan untuk mempresentasikan hasil diskusinya. Sebelum pembelajaran di akhiri, pendidik memberikan tanggapan terhadap proses pembelajaran yang telah berlangsung. Memberikan motivasi kepada siswa yang masih kurang aktif dan memberikan pujian terhadap siswa yang sudah aktif.

Dalam pelaksanaannya diperoleh keaktifan siswa sudah mencapai hasil yang optimal. Berdasarkan proses pembelajaran berlangsung di dalam kelas dari jumlah 36 siswa, yang hadir mengikuti pelajaran berjumlah 35 siswa. 35 siswa ini yang dapat dikategorikan aktif sebanyak 26 siswa yang aktif, sedangkan 9 siswa masih tergolong dalam siswa yang pasif. Berikut gambar 1 diagram keaktifan siswa.

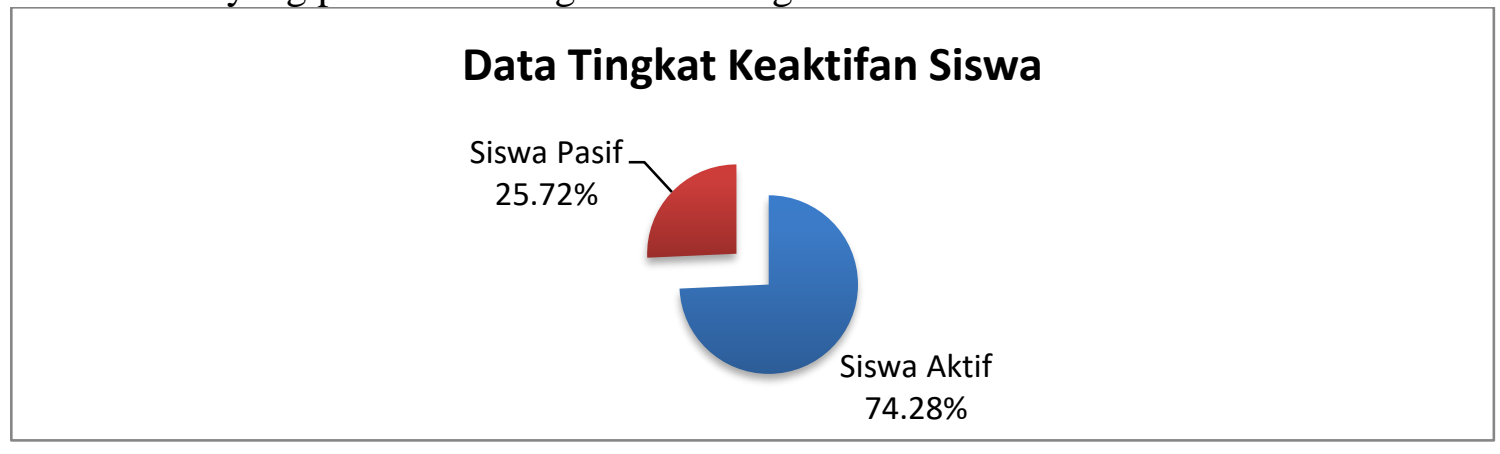




\section{Hasil Tahap Observasi}

\section{Gambar 1. Diagram Data Tingkat Keaktifan Siswa}

Observasi dilaksanakan untuk mengamati pembelajaran yang sedang berlangsung. Adapun yang menjadi observer selain peneliti yaitu tim kolaborator. Pada tahap ini diperoleh beberapa fakta yang menunjukkan bahwa dalam proses pembelajaran pendidik berpedoman pada RPP yang telah disusun. Selain itu, siswa dengan antusias mengikuti pembelajaran. Hal ini terlihat saat pembentukan kelompok dimulai dan mendiskusikan artikel untuk memberikan kritik. Akan tetapi, tidak semua kelompok menjalankan tugasnya dengan baik. Ada satu kelompok yang masih terlihat ramai dan mengerjakan tidak sungguh-sungguh, hal ini terlihat ketika kelompok tersebut diminta menjawab pertanyaan dan memberikan kritik hasilnya kurang maksimal. Kelompok hanya menjawab pertanyaan tanpa dijabarkan.

Dinamika kelompok berjalan dengan baik. Banyak siswa yang langsung berdiskusi ketika kelompok dibentuk. Tetapi ada beberapa kelompok yang kurang kompak dalam kelompok, dalam artian hanya satu anak yang mengerjakan. Namun hal itu dapat diatasi oleh peneliti, dengan cara mendekati kelompok tesebut kemudian memberikan motivasi untuk mengikuti diskusi dalam kelompok. Akhirnya siswa yang tidak ikut bergabung pun kemudian ikut terlibat dalam diskusi kelompok. Akan tetapi, masing-masing kelompok masih malu-malu dalam menyampaikan kritik yang telah mereka bahas. Meskipun demikian, dinamika kelompok berjalan lancar dan sesuai dengan rencana.

\section{Hasil Uji N.Gain}

Pretest

Didapatkan data pretest pada kelas eksperimen sebagai berikut:

Tabel 2. Hasil Pretest

\begin{tabular}{lccccc}
\hline Kelompok & N & Skor Ideal & $\begin{array}{c}\text { Nilai } \\
\text { Minimum }\end{array}$ & $\begin{array}{c}\text { Nilai } \\
\text { Maksimum }\end{array}$ & Rerata \\
\hline Eksperimen & 35 & 100 & 60 & 75 & 67.6 \\
\hline
\end{tabular}

Berdasarkan Tabel 2 dapat dilihat rerata pretest kelompok eksperimen adalah 67.6.

\section{Post test}

Didapatkan data posttest pada kelas eksperimen sebagai berikut:

Tabel 3. Hasil Posttest

\begin{tabular}{cccccc}
\hline Kelompok & N & Skor Ideal & $\begin{array}{c}\text { Nilai } \\
\text { Minimum }\end{array}$ & $\begin{array}{c}\text { Nilai } \\
\text { Maksimum }\end{array}$ & Rerata \\
\hline Eksperimen & 35 & 100 & 80 & 95 & 87.7 \\
\hline
\end{tabular}

Berdasarkan Tabel 3 dapat dilihat rerata posttest kelompok eksperimen adalah 87.7.

Selanjutnya tahap akhir dalam penelitian ini dengan melakukan evaluasi. Pada tahap ini hasil tes keterampilan berpikir tingkat tinggi berbasis strategi metakognitif problem solving yang mencakup pretest dan postest dianalisis, kemudian dilihat peningkatannya. Berikut tabel 4 hasil perhitungan yang diperoleh.

\section{Tabel 4. Hasil Pretest dan Postest}

\begin{tabular}{cc}
\hline Keterangan & Hasil \\
\hline Rata-rata nilai pretest & 67.6 \\
\hline Rata-rata nilai posttest & 87.7 \\
\hline
\end{tabular}


Skor maksimal 100

Dari hasil tabel di atas diperoleh perhitungan Gain Score sebagai berikut:

$g=\underline{87.7-67.6}$

$100-67.6 \mathrm{~g}$

$=0.62$

Tabel 5. Hasil Uji Gain Score

\begin{tabular}{|c|c|c|c|c|c|c|}
\hline Kelompok & $\begin{array}{l}\text { Rerata } \\
\text { Pretest }\end{array}$ & Skor & $\begin{array}{l}\text { Rerata } \\
\text { Posttest }\end{array}$ & Skor & $\begin{array}{l}\text { N-Gain } \\
(100 \%) \\
\end{array}$ & Kategori \\
\hline Eksperimen & 67.6 & & 87.7 & & 0.62 & Sedang \\
\hline
\end{tabular}

Berdasarkan data yang diperoleh pada Tabel 5 dapat dilihat rerata N-Gain kelompok eksperimen adalah 0,62 kategori sedang. Maka dapat disimpulkan bahwa NGain pada kelas eksperimen terjadinya peningkatan nilai N-Gain menunjukan terjadinya peningkatan keterampilan berpikir tingkat tinggi berbasis strategi metakognitif problem solving siswa. Peningkatan tersebut menunjukkan efektivitas penggunaan strategi metakognitif problem solving.

Berdasarkan hasil penelitian ini diperoleh rerata nilai pretest adalah 67.6 dan rerata nilai posttest adalah 87.7. selanjutnya uji $N$-Gain kelompok eksperimen adalah 0,62 kategori sedang. Maka dapat disimpulkan bahwa N-Gain pada kelas eksperimen terjadinya peningkatan nilai $\mathrm{N}$-Gain menunjukan terjadinya peningkatan keterampilan berpikir tingkat tinggi berbasis strategi metakognitif problem solving siswa. Peningkatan tersebut menunjukkan efektivitas penggunaan strategi metakognitif problem solving.

Penelitian ini sesuai dengan Tan (2004) yang menyatakan bahwa dengan penyajian masalah, maka rancangan pemecahan masalah dan tahapannya membantu siswa mengembangkan rangkaian hubungan kognitif. Dengan mengumpulkan data dan informasi lebih banyak untuk menyelesaikan masalah, siswa menerapkan kemampuan berpikir analitis, seperti merepresentasikan, membandingkan, mengklasifikasikan, dan menyimpulkan. Siswa akan menentukan strategi belajarnya serta membandingkannya dan membagi dengan teman lain dalam usaha untuk memecahkan masalah. Kesadaran atas pemikiran sendiri untuk mengarahkan, membandingkan, dan membagi strategi belajarnya menunjukkan bahwa siswa terlibat dalam belajar bagaimana belajar, yang akan mengembangkan metakognisinya (Tan, 2004).

Problem solving secara langsung banyak menghasilkan kelebihan dan rekomendasi. Duch et. al. (2001) mengidentifikasi sebagai berikut: (1) berpikir kritis dan mampu untuk menganalisis dan memecahkan yang kompleks, masalah nyata, (2) mencari, mengevaluasi, dan menggunakan sumber daya yang tepat belajar, (3) bekerja secara kooperatif dalam tim dan kelompok-kelompok kecil, (4) mendemonstrasikan keterampilan komunikasi serbaguna dan efektif, baik lisan dan tertulis, (5) menggunakan pengetahuan dan keterampilan intelektual yang diperolehnya untuk memecahkan masalah selanjutnya.

Nurdin (2016) mengemukakan bahwa pembelajaran berbasis masalah merupakan salah satu pendekatan pembelajaran yang digunakan untuk merangsang berpikir tingkat tinggi siswa dalam situasi yang berorientasi pada masalah yang nyata, termasuk di dalamnya belajar bagaimana belajar.

Jadi, dengan menerapkan model pembelajaran problem solving mengkondisikan siswa untuk mengembangkan kemampuan berpikir setahap demi setahap mulai dari mendefinisikan masalah, mencari data, menganalisis, kemudian menyuguhkan alternatif. Hal ini merangsang siswa untuk mengembangkan kemampuan berpikir 
analisis dan evaluasinya atau berpikir kritis, logis, reflektif, metakognitif, dan berpikir kreatif. Hal ini juga sejalan berdasarkan hasil penelitian Rokhman (2014), penerapan model pembelajaran problem solving dapat digunakan sebagai alternatif dalam pembelajaran untuk meningkatkan kemampuan berpikir kritis.

Hal ini didukung oleh Hollingword dan McLoughlin (2002) yang menyatakan bahwa kemampuan metakognisi yang dimiliki, membimbing siswa menyusun lingkungan belajar dan memilih strategi untuk memperbaiki kinerja kognisi pada masa yang akan datang dan dapat meningkatkan hasil belajar, khususnya daya ingat dan pemahaman. Hal ini juga didukung oleh Anderson dan Nashon (2006) yang menyatakan bahwa kemampuan metakognisi yang dimiliki siswa dapat meningkatkan kapasitas belajar yang penuh makna dan membentuk serta mempengaruhi untuk mengkonstruksi pemahaman.

\section{PENUTUP}

Strategi metakognitif problem solving dikembangkan sesuai paradigma konstruktivistik. Problem solving merupakan strategi pembelajaran berbasis pemecahan masalah di mana siswa mengembangkan kemampuan berpikir yaitu bagaimana mendefinisikan masalah, mencari data, menganalisis, kemudian menyuguhkan alternatif. Siswa dirangsang mengembangkan kemampuan berpikir secara kritis, logis, reflektif, metakognitif, dan berpikir kreatif.

Melalui proses pemecahan masalah, siswa lebih mudah menggali ide-ide yang berkaitan dengan konsep esensial, memperdalam konsep sehingga ide-ide yang muncul dapat dikembangkan. Hal ini disebabkan karena pengetahuan metakognisi membimbing siswa menyusun lingkungan belajar dan memilih strategi yang tepat, siswa menjadi semakin percaya diri dan menjadi pembelajar yang mandiri, menyadari bahwa mereka dapat memenuhi kebutuhan intelektual, menemukan banyak informasi, dan menyadari bahwa disaat mereka menghadapi masalah akan mencoba mencari jalan keluar. Dengan demikian penerapan strategi tersebut mampu mengembangkan keterampilan berpikir tingkat tinggi siswa.

\section{DAFTAR PUSTAKA}

Akkaya, N. 2011. Effect of Using Reading Comprehension Strategies on the Attitude and Success at Elementary School 8th Grade Turkish Course. Student Attitudes (47-57). Upper Galilee: Nova Publisher.

Aljaberi, N. M. 2015. University Student's Level of Metacognitive Thinking and Their Ability to Solve Problems. American International Journal of Contemporary Research. vol, 5, No 3; Juni 2015.

Anderson, D. \& Nashon, S. 2006. Predators of Knowledge Construction: Interpreting Students 'Metacognition in an Amusement Park Physics Program.

Anderson, Lorin W \& Krathwohl, David R. 2001. Learning, Teaching, and Assessing: A revision of Bloom's Taxonomy of Educational Objectives. Longman; NY.

Aprianti, Vika. 2013. Pengaruh Penerapan Model Cooperative Learning Tipe Think Pair Share (TPS) Terhadap Kemampuan Berpikir Kritis Siswa pada Pembelajaran Ekonomi. UPI. repository.upi.edu.

Asay \& Schneider, EW. 1976. The Effect of Untrainned Student Generated Highlighting on Learning. Paper presented at the Meeting of the Northestern Educational Research Association ,Ellensville,New York.

Bransford, J., Sherwood, R., Vye, N., \& Rieser, J. 1986. Teaching Thinking and Problem Solving: Researchfoundations. American Psychologist , 41 (10), 1078.

Carlson, M. P. \& Bloom, I. 2005. The Cyclic Nature of Problem Solving: An emergent Multidimensional Problem Solving framework. Educational Studies in 
Mathematics, 58(1). 45- 75.

Duch, B. J. 2001. The Power of Problem Based Learning. Virginia: Stylus Publishing.

Edmondson, K.M, 1994 Concept maps and teh development of cases for problem based learning, Journal of the Association of American Medical Colleges, 69 (2), 1994 $108-110$

Flavell, J. 1976 Metacognition and cognitive monitoring. American Psychologist, 34(10), 906-911

Flavell, J. H. 1981. Monitoring social cognitive enterprises: Something else that may develop in the area of social cognition. In J. H. Flavell \& L. Ross (Eds.), Social cognitive development: Frontiers and possible futures (pp. 272-287). New York:: Cambridge University Press.

Friend, R. 2001. Teaching Summarization as a Content Area Reading Strategy. Journal of Adolescent and Adult Literacy. 44 (4). 320.

Gok, T. 2010. The General Assessment of Problem Solving Processes in Physics Educatioon. Gok,

Hafid, Abdul. 2007. Mengembangkan Kemampuan Berpikir Kritis Melalui Teknik Problem Solving. Jurnal Iktiyar, Vol. 5, No. 3, Issn 1412-8535, hal 126-277.

Hake \& Richard, R. 2002. Relationship of Individual Student Normalized Learning Gains in Mechanics with Gender, HighSchool Physics, and Pretest Scores on Mathematics and Spatial Visualization. Tersedia: http://www.physics.indiana. edu/ hake. [21 September 2008].

Hattie. J 2009. Visible Learning; A Synthesis of Over 800 Meta Analyses Relating to Achivement, Routledge, Oxon, New York.

Henk, W.A., \& Stahl, N,A 1985. A meta-analysis of the effect of notetaking on learning from lecture. ERIC Document Reproduction Services No.258b533. Atlanta, GA: Georgia State University.

Heong, Y. M. 2011. The Level of Marzano Higher Order Thinking Skills Among Technical Education Students. International Journal of Social and humanity, Vol. 1,No. 2, July 2011, 121-125.

Hollingworth, R. \& McLoughlin. 2002. The Development of Metacognitive Skilss among Firts Year Science Student. Tersedia http://fyhe.Qut.Edu.au./FYHEPrevious/Papers/HollingworthPaper.doc.

Jitendra, A., \& Gajria, M. 2010. Reading comprehension instruction for students with learning disabilities. Focus on Exceptional Children., 43 (8), 1-13.

Kiewra K A, \& Fletcher, HJ. 1984. The relationship between levels of note-taking and achivement. Human Learning, 3, 273-280.

Kirkgoz.Y. 2010. Promoting students' note taking skills through task-based learning. Procedia Social and Behavioral Science (2) 4346-4351

Kuhn, D. 2000. Theory of Mind, Metacognition and Reasoning: A life-span Perspective. In P. Mitchell \& K. J. Riggs (Eds.). Children's Reasoning and The Mind (pp. 301326). Hove, UK: Psychology Press.

Kriswianti, Th. (2011). Profil Metakognisi Siswa Kelas Akselerasi dan Nonakselerasi SMA dalam Memecahkan Masalah Matematika ditinjau dari Perbedaan Gender. Disertasi. Surabaya: UNESA.

Leutwyer, B. 2009. Metacognitive Learning Strategies: Differential Development Patterns in High School, Metacognitive Learning 4:111-123 Mason, C.L (1992) Concept mapping : A tool to develop reflective science instruction, Science Education 76 (1) 51-63, John Wiley and Son

Limbach. B \& Waugh.W. 2009. Developing Higher Level Thinking. Journal of Instructional Pedagogies: Chadron State College. 
Longman, D. \& Atkinson, R. 1999. College Learning and Study Skills. USA: Wadsworth/ Thopmson Learning.

Mayer, R. 1998. Cognitive, Metacognitive, and Motivational Aspets of Problem Solving. Instructional science. 26 (1-2), 49-63.

Novak, J.D, Gowin, B.D, Johansen, G.T. 1984. The use of concept mapping and knowledge vee mapping with junior high school science students. Science Education. 67 (5) 625-645.

Nurdin, Syafrududdin, Adriatoni. 2016. Kurikulum dan Pembelajaran. Jakarta: PT RajaGrafindo Persada.

O'Neil, H.F., \& Schacter, J. 1997. Test Specifications for Problem Solving Assessment. Center for the Study of Evaluation, National Center for Research on Evaluation, Standards, and Student Testing. Graduate Schoolof Education \& Information Studies. University of California: Los Angeles.

Ponce. C.W. 2000. Summarization instruction:Efects on foreign comprehension and summarization of expository texts'. Literacy Research and Instruction. 39 (4) 329-350J.

Riyadi, Iswan. 2010. Pembelajaran Berbasis Metakognisi untuk Peningkatan Kompetensi Siswa. Disertasi. UPI: Bandung.

Rokhman, Ayla Yuli. 2014. Perbandingan Model Pembelajaran Problem Based Learning dan Problem Solving Terhadap Kemampuan Berpikir Kritis Pada Materi Pelestarian Lingkungan Hidup Siswa XI IPS MAN 3 Malang.Skripsi. Malang: Universitas Negeri Malang.

Sudiarta, P. 2006. Pengembangan model pembelajaran berorientasi pemecahan masalah open-ended berbantuan LKM untuk meningkatkan pemahaman konsep dan hasil belajar siswa matakuliah pengantar dasar Matematika. Jurnal Pendidikan dan Pengajaran UNDIKSHA 39 Nomor 2, April 2006. Singaraja: UNDIKSHA.

Sudjana. I.W. 2012. Pengaruh Jenis Pendekatan Pembelajaran dan Tingkat Kemampuan Berpikir Kreatif Terhadap Perolehan Belajar IPS pada Siswa Kelas VI SD 17 Dauh Puri Denpasar. Tesis. Malang: PPS UM.

Sudjimat, D.A. 1996. Pembelajaran Pemecahan Masalah. Tinjauan Singkat Berdasar Teori Kognitif. Jurnal Pendidikan Himaniora dan Sains @ (1\&2). hlm. 24-32.

Susan, Imel. 2002. Metacognitive Skills for Adult Learnin. (online). HYPERLINK http://www.ce-" (http://www.ce te.org/ acve/docs/tia00107.pdf. Diakses 3 September 2012.

Tan, O. S. 2004. Enhanching Thinking Problem Based Learning Approached. Singapura: Thomson.

Vaidya, S. R. 1999. Metacognitive Learning Strategies for Students with Learning Disabilities. Education, 120 (1), 186-191.

Veenman, M. V. Nad Span. 2005. The Assement of Matacognitive Skill: What can be Learned from Multi - Method Design. Metacognition Learning 4. 235-251

Wikefiel, J.F. 1992. Creative Thinking: Problem Solving Skill and The Arts Orientation. New Jersey: Ablex Publishing Coorporation.Wiley InterScience.

Woolfolk, A. 2008. Educational Psychology Active earn- ing Edition $10^{\text {th }}$ ed. Pearson Education, Inc.

Woolley, G. 2010. Developing reading comprehension: combining visual and verbal cognitive processes. Australian Journal of Language and Literacy. 33(2), 108125 .

Wormeli, R. 2004. Summarization in any Subjects: 50 techniques to improve student learning. Alexaandria, VA USA: Association for supervision \& Curriculum Development. 